\title{
Antifungal activity of selected plant extracts against Trichothecium roseum (Pers.) Link (1809) (Sordariomycetes: Hypocreales), causal organism of fungal rot of Solanum melongena L. (Solanales: Solanaceae) in Kashmir, India
}

\section{Jahangir Abdullah Koka ${ }^{1, *}$, Abdul Hamid Wani ${ }^{1}$, Mohd Yaqub Bhat $^{1}$, Shazia Parveen ${ }^{1}$, Mohammad Afaan Fazili ${ }^{2}$ and Nusrat Ahmad $^{1}$}

\begin{abstract}
${ }^{1}$ Section of Mycology and Plant Pathology. Department of Botany. University of Kashmir. Hazratba. Srinagar, 190006. Jammu \& Kashmir. India. *Email: kokajahangir76@gmail.com.

${ }^{2}$ Cytogenetics and Plant Breeding Laboratory. Department of Botany. Aligarh Muslim University. Aligarh, 202002. Uttar Pradesh. India.
\end{abstract}

\begin{abstract}
Egg plant Solanum melongena L. (Solanales: Solanaceae) is an important vegetable grown in Kashmir. It is attacked by number of fungal pathogens in storage and in the field. These fungi caused several fungal rot diseases resulting heavy losses to the growers. Therefore, present study was carried out to study the incidence and management of fungal rot of egg plant using some selected plant extracts. It was revealed from the study that Trichothecium roseum (Pers.) Link (1809) (Sordariomycetes: Hypocreales) causing decaying of egg plant under storage. Study was also undertaken to evaluate the efficacy of some plant extract against Trichothecium roseum on inhibition of spore germination and mycelial growth under in vitro conditions. It was observed from the results that amongst the plant extracts, plant extract of Ajuga bracteosa at highest concentration was found most effective against Trichothecium roseum and cause highest inhibition in the mycelial growth and spore germination followed by plant extract of Taraxicum officinale, Mentha arvensis and Iris kashmiriana at the same concentrations. Other concentrations of plant extracts also bought about significant reduction in mycelial growth and spore germination of the test fungus but to a lesser extent as compared to control.
\end{abstract}

Keywords: Pink rot; Botanical fungicides; Inhibition; Mycelia growth; Spore germination; Brinjal.
Received

July 11, 2018

Accepted

February 13, 2019

Released

April 30, 2019

Full Text Article

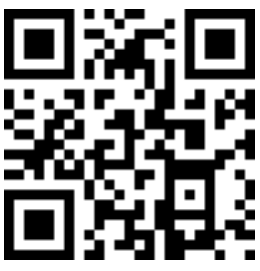

ORCID

(1) 0000-0003-0040-1624 Jahangir Abdullah Koka

(1) 0000-0002-6157-9656 Abdul Hamid Wani

(1) 0000-0002-0582-4813 Mohd Yaqub Bhat 


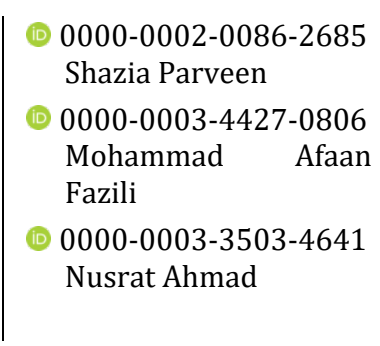

\section{Introduction}

Vegetables are important constituents of human diet. They are important sources of carbohydrates, minerals and vitamins. They are attacked by many pathogens like fungi and bacteria that result in loss of fresh produce (Mitcham and Mitchell, 2002; Wani, 2011). Losses from the postharvest diseases in fresh produce fall into two categories i.e., loss in quantity and quality. Loss in quantity occurs where deep penetration of decay occurs in the infected vegetables. This is often as a result of infection of the vegetables in the field before harvest. Loss in quality occurs when the diseases affects only the surface of the vegetables. It may cause skin blemishes that can lower the value of the commercial crop. Rot diseases cause greatest losses to the vegetables in storage as well as in fields (Snowdon, 2003; Bashar et al., 2012).

Egg plant Solanum melongena L. belongs to Family Solanaceae and is indigenous vegetable crop of India including Kashmir. It contributes $9 \%$ of the total vegetable production of the country. China is the largest producer of brinjal followed by India. It is grown in India over an area of 0.4 million hectors with an annual production of 7.8 million tonnes (Datar, 1999). Post harvest decays of fruits and vegetables account for significant levels of post harvest losses. It is estimated that about $20 \%-25 \%$ of the harvested fruits and vegetables are decayed by pathogens during post-harvest handling even in developed countries (El-Ghaouth et al., 2004; Droby et al., 2009; Abano and SanAmaoh, 2012). In developing countries, post harvest losses are often more severe (more than 30\%) due to inadequate post harvest handling, packaging, transportation and storage which may result in decay and production by microorganisms which become activated because of the changing physiological state of the fruit (Tripathi and Dubey, 2004; Korsten, 2006; Singh and Sharma, 2007).

It has been reported that on an average, the oblong-fruited eggplant cultivars are rich in total soluble sugars, whereas the long-fruited cultivars contain a higher content of free reducing sugars, anthocyanin, phenols, glycoalkaloids (such as solasodine), dry matter, and amide proteins (Bajaj et al., 1979). The glycoalkaloid contents in the Indian commercial cultivars vary from $0.37 \mathrm{mg} / 100 \mathrm{~g}$ fresh weight to $4.83 \mathrm{mg}$ ) (Bajaj et al., 1981). Brinjal is known to have ayurvedic medicinal properties and is good for diabetic patients. It has also been recommended as an excellent remedy for those suffering from liver complaints (Shukla and Naik, 1993). To the best of our knowledge, this is the first report of $T$. roseum causing pink rot on Brinjal in Kashmir region of Jammu and Kashmir, India. Various chemical fungicides have been used to control these fungal rot diseases, but these fungicides cause hazardous effect on humans and environment. Hence strong regulatory actions have been imposed on their use. So there is a strong need to control these diseases in an ecofriendly way.

Various biocontrol fungi and extracts obtained from many medicinal plants have gained much popularity and scientific interest for their antifungal and 
antibacterial activities (Parveen et al., 2016; Koka et al., 2017). They are believed to be less hazardous than chemical fungicides and can therefore be used as an alternative to control fungal rot diseases (Jobling, 2000). The use of these plant extracts for inhibition of fungal diseases is an important step towards the assessment of the degree of variability among the diverse natural flora (Khandare and Vasait, 2017). The antifungal activities of these plant extracts are attributed to different chemical compounds like phenols, flavonoids, isoflavonoids, coumarins, pyrones, alkaloids, etc. present in these plants which effect the growth of pathogenic fungi (Jantasorn et al., 2016). Hence these plant extracts may have potential as a new natural fungicide for management of fungal rot pathogens. So in an approach towards ecofriendly management strategy, an attempt was made to study the efficacy of some plant extracts against Trichothecium roseum causal organism of fungal rot of brinjal in Kashmir.

The present study was carried out to evaluate the effect of different concentrations of plant extracts on mycelia growth and spore germination of Trichothecium roseum causing pink rot of brinjal.

\section{Materials and methods}

To investigate the fungi which cause the rotting of brinjal fruits in Kashmir Valley, diseased brinjal fruits were collected in separate polythene bags from different fields, markets, godowns and storage houses of Kashmir valley. These samples were either used immediately or stored at $10^{\circ} \mathrm{C}$ in the laboratory for different pathological studies.

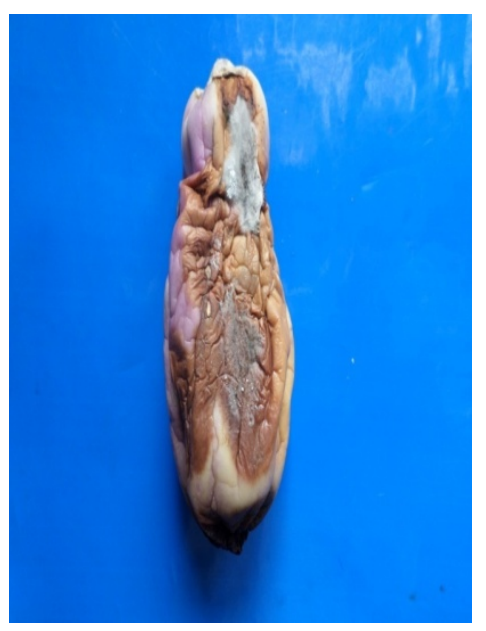

Figure 1. Infected brinjal fruit.

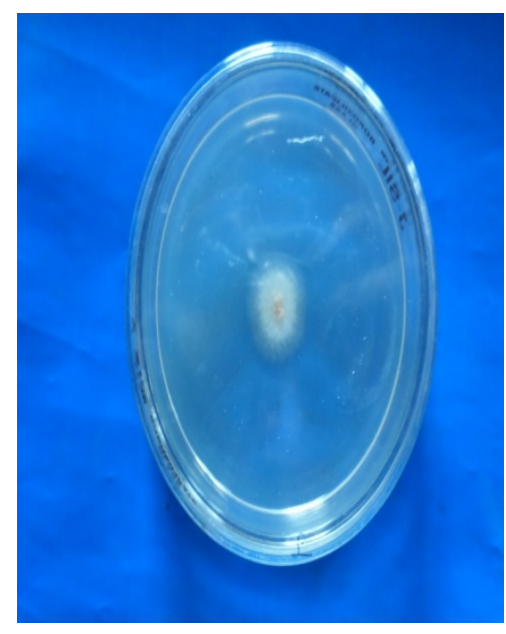

Figure 2. Culture of T. roseum on PDA (Trichothecium possess pinkish colored colonies).

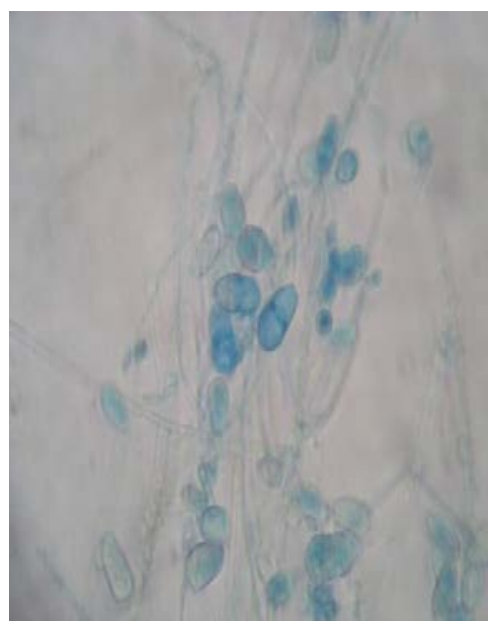

Figure 3. Conidiophore with conidia of $T$. roseum (100x) (Conidiophore was simple hyphae, septate in their lower half and bear clusters of conidia at the tip. Conidia of T. roseum were smooth and clavate).
Small portions of rotted tissues were cut out aseptically from the diseased brinjal fruits and transferred to Potato Dextrose Agar medium (PDA).
The casual pathogen was identified on the basis of symptoms caused by the fungus on brinjal fruits, cultural and microscopic characteristics. The fungus 
on Potato Dextrose Agar medium (PDA) after $48 \mathrm{~h}$ of inoculation at $24^{\circ} \mathrm{C} \pm 2{ }^{\circ} \mathrm{C}$, produced white colonies and then due to conidial production the colonies turn light pink in colour (Figure 1, 2, and 3).

Pure colony cultures were obtained by sub-culturing the fungal growth in separate Petri plates containing the same medium. A pink rot fungus was identified by their morphological, reproductive and cultural characteristics (Ellis, 1971; Barnett and Hunter, 1972; Watanabe, 2002; Gilman, 2008).

For pathogenicity, pathogens were re-inoculated after isolation onto the healthy brinjal fruits (Tomkin and Trout, 1931). Then all the five brinjal fruits were kept in clean polythene bags and incubated at $25^{\circ} \mathrm{C} \pm 2{ }^{\circ} \mathrm{C}$ for ten days. These pathogenicity tests were used for the identification of plant pathogens and to confirm the detection of a particular disease. Identification of the disease and the pathogen was done following Koch's postulates. Parameters such as symptoms caused by these fungi on the healthy brinjal fruits, cultural characteristics of the pathogens and microscopic features of the pathogens were studied.

\section{Preparation and evaluation of different concentrations of plant extracts}

Different concentrations (i.e., S, $\mathrm{S} / 2, \mathrm{~S} / 5$ and $\mathrm{S} / 10$ ) of aqueous extracts of leaves of Ajuga bracteosa Wall ex Benth, Taraxacum officinale Weber ex Wiggers, Mentha arvensis L. and Iris kashmiriana Baker were evaluated for their effect on the inhibition in mycelial growth and in spore germination of Trichothecium roseum isolated from decayed brinjal fruits.
To prepare various concentrations of plant extracts leaves were collected, cleaned and cut into small pieces before being dried under shade at room temperature. The dried material was ground to fine powder using a mechanical blender. Dry leaf powder (200 g) was packed in Soxhlet apparatus and extracted with distilled water at $80{ }^{\circ} \mathrm{C}-85^{\circ} \mathrm{C}$. The extracts were filtered through Whatmann filter paper No. 1 and the solvent was removed under reduced pressure at $35^{\circ} \mathrm{C}-45^{\circ} \mathrm{C}$ using rotavapor.

The dried extract $(5 \mathrm{mg} / 5 \mathrm{~mL})$ was considered as standard solutions (S) and stored at $4{ }^{\circ} \mathrm{C}$ in storage vials for experimental use (Kaul, 1997). Then other concentrations such as $\mathrm{S} / 2, \mathrm{~S} / 5$ and $\mathrm{S} / 10$ were obtained by adding appropriate amount of sterilized distilled water to the standard concentration. These concentrations were evaluated for their effect on the mycelial growth by food poisoning technique (Adams and Wong, 1991). $1 \mathrm{~mL}$ from each concentration of the plant extract was mixed with nine $\mathrm{ml}$ of autoclaved and cooled PDA just before pouring into Petri plates. The medium was then dispensed uniformly into $90 \mathrm{~mm}$ sterile Petri plates and then inoculated with $5 \mathrm{~mm}$ mycelial disc of the pathogen from 10 day old fungal culture. Three replicates were maintained for each concentration including the control without any treatment. The Petri plates were incubated at $25^{\circ} \mathrm{C} \pm 2{ }^{\circ} \mathrm{C}$ and observations of the mycelial growth of test fungus were recorded after seven days of incubation.

The percent inhibition in fungal growth due to various treatments at different concentrations was computed as follows:

\section{Mycelial growth inhibition $(\%)=\{(\mathrm{dc}-\mathrm{dt}) / \mathrm{dc}\} \times 100$}

Where:

$\mathrm{dc}=$ average diameter of fungal colony in control, and

$\mathrm{dt}=$ average diameter of fungal colony in treatment group. 
The plant extracts of tested plants were also evaluated for their effect on the spore germination of Trichothecium roseum. Spore suspension was prepared from 10 days old fungal culture. A drop about $0.1 \mathrm{~mL}$ of spore suspension was then placed in a cavity glass slide containing a drop (about $0.1 \mathrm{~mL}$ ) of different concentration of plant extract and then incubated at $25^{\circ} \mathrm{C} \pm 2{ }^{\circ} \mathrm{C}$ for $24 \mathrm{~h}$ in a moist chamber created in $100 \mathrm{~mm}$ Petri plates by covering both sides of the Petri plates with moist filter paper to maintain enough humidity. Three replicates were maintained for each treatment including the control. The slides were examined after $24 \mathrm{~h}$ by hand tally methods at different microscopic fields. Percent spore germination for each was recorded using formula given by Kiraly et al. (1974).

\section{Percent spore germination $=($ No. of spores germinated $/$ Total no. of spores examined) $\times 100$}

\section{Statistical analysis}

Statistical analysis was carried out using SPSS statistical software (version 16.0). Data was analyzed by one way analysis of variance (ANOVA) and comparison of the means was done by Duncan multiple comparison tests at $\mathrm{P} \leq 0.05$.

\section{Results}

\section{Effect of different concentrations of plant extracts on the mycelial growth of $T$. roseum \\ It was revealed from the results} (Table 1) that different concentration of plant extracts caused significant inhibition in the mycelial growth of Trichothecium roseum as compared to control. However, the maximum inhibition in mycelial growth was found at highest concentration ' $\mathrm{S}$ ' followed by lower concentrations $\mathrm{S} / 2, \mathrm{~S} / 5$ and $\mathrm{S} / 10$ of the plant extracts. Among the plant extracts used Ajuga bracteosa at highest concentration ' $\mathrm{S}$ ' was found most effective against Trichothecium roseum and cause highest inhibition in the mycelial growth $(42.52 \%)$ followed by Taraxacum officinale (34.03\%), Mentha arvensis (29.75\%) and Iris kashmiriana $(25.54 \%)$ at the same concentration.

Other concentrations of plant extracts also bought about significant reduction in the mycelial growth but to a lesser extent. In different concentrations of Ajuga bractosea, the inhibition in mycelial growth ranges from $42.52 \%$ to $23.37 \%$ and in $T$. officinale, the inhibition in mycelial growth ranges from $34.03 \%$ to $4.21 \%$, respectively. Likewise, the inhibition in mycelial growth in different concentrations of Mentha arvensis ranges from $29.75 \%$ to $14.87 \%$ and in Iris kashmiriana the inhibition ranges from $25.54 \%$ to $19.15 \%$, respectively. 
Table 1. Effect of different concentrations of plant extracts on the mycelial growth of Trichothecium roseum.

\begin{tabular}{|l|c|c|c|c|c|}
\hline \multirow{2}{*}{} & \multicolumn{5}{|c|}{ Mycelial growth (mm) } \\
\cline { 2 - 6 } & $\mathbf{S}$ & $\mathbf{S} / \mathbf{2}$ & $\mathbf{S} / \mathbf{5}$ & $\mathbf{S} / \mathbf{1 0}$ & Control \\
\hline \multirow{2}{*}{ Ajuga bracteosa } & $\begin{array}{c}9.00 \pm 1.00^{\mathrm{c}} \\
(45.52 \%)\end{array}$ & $\begin{array}{c}10.00 \pm 1.0^{\mathrm{c}} \\
(36.14 \%)\end{array}$ & $\begin{array}{c}11.66 \pm 0.57^{\mathrm{b}} \\
(25.54 \%)\end{array}$ & $\begin{array}{c}12.00 \pm 1.00^{\mathrm{b}} \\
(23.37 \%)\end{array}$ & $15.66 \pm 0.57^{\mathrm{a}}$ \\
\hline Taraxicum officinale & $\begin{array}{c}10.33 \pm 0.57^{\mathrm{b}} \\
(34.03 \%)\end{array}$ & $\begin{array}{c}11.33 \pm 1.15^{\mathrm{b}} \\
(27.65 \%)\end{array}$ & $\begin{array}{c}14.33 \pm 0.57^{\mathrm{a}} \\
(8.49 \%)\end{array}$ & $\begin{array}{c}15.00 \pm 1.00^{\mathrm{a}} \\
(4.21 \%)\end{array}$ & $15.66 \pm 0.57^{\mathrm{a}}$ \\
\hline Mentha arvensis & $\begin{array}{c}11.00 \pm 1.00^{\mathrm{c}} \\
(29.75 \%)\end{array}$ & $\begin{array}{c}12.00 \pm 1.00^{\mathrm{b}} \mathrm{bc} \\
(23.37 \%)\end{array}$ & $\begin{array}{c}12.66 \pm 1.15^{\mathrm{bc}} \\
(19.15 \%)\end{array}$ & $\begin{array}{c}13.33 \pm 0.57^{\mathrm{b}} \\
(14.87 \%)\end{array}$ & $15.66 \pm 0.57^{\mathrm{a}}$ \\
\hline Iris kashmiriana. & $\begin{array}{c}11.66 \pm 0.57^{\mathrm{b}} \\
(25.54 \%)\end{array}$ & $\begin{array}{c}12.00 \pm 1.00^{\mathrm{b}} \\
(23.37 \%)\end{array}$ & $\begin{array}{c}12.33 \pm 2.08^{\mathrm{b}} \\
(21.26 \%)\end{array}$ & $\begin{array}{c}12.66 \pm 1.52^{\mathrm{b}} \\
(19.15 \%)\end{array}$ & $15.66 \pm 0.57^{\mathrm{a}}$ \\
\hline
\end{tabular}

*Each value is mean of 3 replicates \pm SD. Figures in parenthesis is the mycelial growth inhibition $(\%)$

\section{Effect of different concentrations of plant extracts on the spore germination of $T$. roseum \\ It was observed from the results} (Table 2) that different concentrations (S, S/2, S/5 and S/10) of plant extracts caused significant reduction in spore germination of $T$. roseum compared to control. Among the plant extracts used, $A$. bractosea at highest concentration (S) was found most effective and caused highest reduction in spore germination followed by $T$. officinale, $M$. arvensis $L$. and Iris kashmiriana, respectively, at the same concentration. Other concentrations of plant extracts also bought about significant reduction in spore germination but to a lesser extent. In $A$. bracteosa, the inhibition in spore germination varies from $23.40 \%$ to $18.28 \%$ in different concentrations. In different concentrations of Taraxicum officinale the inhibition varies from $27.42 \%$ to $23.23 \%$ and in Mentha arvensis the inhibition varies from $33.48 \%$ to $26.49 \%$, respectively. Likewise, the inhibition in the spore germination varies from $37.09 \%$ to $29.99 \%$ in different concentrations of Iris kashmiriana, respectively.

Table 2. Effect of different concentrations of plant extracts on the spore germination of Trichothecium roseum.

\begin{tabular}{|l|c|c|c|c|c|}
\hline & \multicolumn{5}{|c|}{ Spore germination (\%) } \\
\cline { 2 - 6 } & $\mathbf{S}$ & $\mathbf{S} / \mathbf{2}$ & $\mathbf{S} / \mathbf{5}$ & $\mathbf{S} / \mathbf{1 0}$ & Control $^{*}$ \\
\hline Ajuga bracteosa & $18.28 \pm 1.67^{\mathrm{c}}$ & $18.78 \pm 1.05^{\mathrm{c}}$ & $22.40 \pm 2.50^{\mathrm{b}}$ & $23.40 \pm 1.43^{\mathrm{b}}$ & $36.05 \pm 2.57^{\mathrm{a}}$ \\
\hline Taraxicum officinale & $23.23 \pm 2.88^{\mathrm{b}}$ & $23.66 \pm 1.52^{\mathrm{b}}$ & $26.02 \pm 3.57^{\mathrm{b}}$ & $27.42 \pm 2.50^{\mathrm{b}}$ & $36.05 \pm 2.57^{\mathrm{a}}$ \\
\hline Mentha arvensis & $26.49 \pm 1.29^{\mathrm{b}}$ & $28.33 \pm 2.88^{\mathrm{b}}$ & $33.01 \pm 2.86^{\mathrm{a}}$ & $33.48 \pm 2.80^{\mathrm{a}}$ & $36.05 \pm 2.57^{\mathrm{a}}$ \\
\hline Iris kashmiriana & $29.99 \pm 3.33^{\mathrm{d}}$ & $32.91 \pm 1.84^{\mathrm{cd}}$ & $35.32 \pm 0.81^{\mathrm{b}^{\mathrm{c}}}$ & $37.09 \pm 0.88^{\mathrm{ab}}$ & $39.41 \pm 0.83^{\mathrm{a}}$ \\
\hline
\end{tabular}

*Each value represents the mean spore germination \%age of 3 replicates \pm SD.

\section{Discussion}

It was clear from the results that brinjal fruits in storage are attacked by Pink rot fungi and caused Pink rot of brinjal. Such studies on fungal rot of brinjal have been carried out for the first time in Kashmir Valley. However, some earlier studies have been carried out on the fungal rot of brinjal in India and all 
over the world. In the present study some plant extracts were evaluated for their antifungal activity against the fungus causing Pink rot of brinjal. $T$. roseum is Isolated from apples (Zabka et al., 2006) and eggplants (Pandey, 2010). Mycotoxins (roseotoxin B and trichothecin) production was carried from T. roseum by Engstrom et al. (1975) and Ghosal et al. (1982). Shamim Shamsi (2008) reported the association of this fungus with chickpea Cicer arietinum $\mathrm{L}$.

Antifungal activities of these plant extracts are attributed to different chemical compounds like phenols, flavonoids, isoflavonoids, coumarins, pyrones, alkaloids, etc. present in these plants which effect the growth of pathogenic fungi (Jantasorn et al., 2016). Hence these plant extracts may have potential as a new natural fungicide for management of fungal rot pathogens.

Presently, Mancozeb proved effective in reducing the losses caused by Trichothecium roseum. Parveen et al. (2013) observed the effect of fungicides and plant extracts on fruit rot pathogens, viz. Alternaria alternata and Mucor piriformis. Likewise, some other studies also revealed the antimycotic activity of some plant extracts against fungi causing fungal rot of vegetables (Oyelana et al., 2011; Raji and Raveendran, 2013; Pawar, 2013).

Dal Bello (2008) reported that Trichothecium roseum causing postharvest fruit rot on tomato fruit for the first time in Argentina. The fungus has been cited causing fruit rot on many crops including tomato (Welch et al. 1975; Farr et al., 2007). It is also clear from the above study that the plant extracts of all the tested plants proved effective against Trichothecium rot pathogen, Trichothecium roseum. Gupta et al. (1996) reported that extracts of Calotropis gigantea and Azadirachta indica were most effective against Fusarium oxysporum Schlecht inhibiting the mycelial growth by $78.5 \%$ and $73.2 \%, \quad$ respectively. Antifungal properties of Azadirachta indica and
Allium sativum extracts against F. oxysporum have also been reported by Thakur et al. (1995). The variation in inhibition among test extracts could be due to variation in the components of antifungal chemicals in different plant species (Gautam et al., 2003).

Sengul et al. (2009) studied that the methanol extract of Inula aucherana, Fumaria officinalis, Crocus sativus, Vicum album, Tribulus terestris, Polygonatum multiflorum, Alkanna tinctoria and Taraxacum officinale were proved to possess considerable antimicrobial potentiality against a number of microorganisms. The methanolic extract had shown better antimicrobial activity compared to aqueous extract. Balkan et al. (2017) screened the fifty plant species for their antifungal effects against T. roseum. Anthemis arvensis, Origanum vulgare, Sambucus ebulus and Thymus longicaulis powders totally inhibited the mycelia growth of $T$. roseum at $10 \%$ $(\mathrm{w} / \mathrm{v})$. Chelidonium majus and Clinopodium vulgare powders were effective to $T$. roseum, with a percentage of inhibition of mycelia growth higher than $70 \%$.

\section{Conclusion}

It is concluded from the study that these plant extracts showed antifungal activity and can possibly be exploited in the management of pathogenic fungi to prevent biodeterioration in an eco-friendly way but after further investigation.

\section{Acknowledgement}

The authors are highly thankful to the Head Department of Botany, University of Kashmir, for providing the necessary facilities for the smooth research and also to Curator, Centre of Biodiversity and Plant Taxonomy, Department of Botany, University of Kashmir, Srinagar, J \& K in proper identification of the plant. 


\section{Conflicts of interest}

Authors declare that they have no conflict of interests.

\section{References}

Abano, E. E.; San-Amoah L. K. Application of antagonistic microorganisms for the control of postharvest decays in fruits and vegetables. International Journal of Advanced Biological Research, v. 2, p. 1-8, 2012.

Adams, P. B.; Wong, J.A. L. The effect of chemical pesticides on the infection of sclerotia of Sclerotinia minor by the biocontrol agent Sporidesmium sclerotivorum. Phytopathology, v. 81, p. 1340-1343, 1991.

Bajaj, K. L.; Kaur, G.; Chadha, M. L. Glycoalkaloid content and other chemical constituents of the fruits of some egg plant (Solanum melongena L.) varieties. Journal of Plant Foods, v. 3, no. 3, p. 163-168, 1979. https://doi.org/10.1080/0142968X.1979.11 904224

Bajaj, K. L.; Kaur, G.; Chadha, M. L.; Sigh, B. P. Polyphenol oxidase and other chemical constituents in fruits of eggplant (S. melongena L) varieties. Vegetable Sciences, v. 8, p. 37-44, 1981.

Balkan, B.; Balkan, S.; Aydogdu, H.; Guler, N.; Ersoy, H.; Askm, B. Evaluation of antioxidant activities and antifungal activity of different plants species against pink mold rot-causing Trichothecium roseum. Arabian Journal for Science and Engineering, v. 42, no. 6, p. 2279-2289, 2017. https://doi.org/ 10.1007/s13369-017-2484-4

Barnett, H. L.; Hunter, B. B. Illustrated genera of Imperfect Fungi. Minneapolis: Burgess Publishing Company, 1972.

Bashar, M. A.; Shamsi, S.; Hossain M. Fungi associated with rotten fruits in Dhaka Metropolis. Bangladesh Journal of Botany, v. 41 , p.115-117, 2012. https://doi.org/ 10.3329/bjb.v41i1.11090

Dal Bello, G. First report of Trichothecium roseum causing postharvest fruit rot of tomato in Argentina. Australasian Plant Disease Notes, v. 3, p. 103-104, 2008. https://doi.org/10.1007/BF03211257
Datar, V.V. Bio efficacy of plant extracts against Macrophomona phaseolina (Tassi) Gold, the incitant of charcoal rot of Sorghum. Journal of Mycology and Plant Pathology, v. 29, p. 251-253, 1999.

Droby, S.; Wisniewski, M.; Macarisinb, D., Wilson, C. Twenty years of postharvest biocontrol research: Is it time for a new paradigm? Postharvest Biology and Technology, v. 52, no. 2, p. 137-145, 2009. https://doi.org/10.1016/j.postharvbio.2008. 11.009

El-Ghaouth, A.; Wilson, C. L.; Wisniewski, M. E. Biologically based alternatives to synthetic fungicides for the postharvest diseases of fruit and vegetables. In: Samh, N. (Ed.). Diseases of fruit and vegetables. The Netherlands: Kluwer Academic Publishers, 2004. v. 2. p. 511-535.

Ellis M. B. Dematiaceous hyphomycetes. England: Commonwealth Mycological Institute, 1971.

Engstrom, G. W.; Delance, J. V.; Richard, J. L.; Baetz, A. L. Purification and characterization of roseotoxin B, a toxic cyclodepsipeptide from Trichothecium roseum. Journal of Agricultural Food Chemistry, v. 23, p. 244253, 1975. https://doi.org/10.1021/jf60198 a 050

Farr, D. F.; Rossman, A. Y.; Palm, M. E.; McCray, E. B. Fungal databases, systematic botany and mycology laboratory, ARS, USDA, 2007. Available from: <http://nt.arsgrin.gov/fungal databases/>. Accessed on Jul. 10,2008

Ghosal, S.; Chakrabarti, D. K.; Srivastava, A. K.; Srivastava, R.S. Toxic 12, 13epoxytrichothecenes from anise fruits infected with Trichothecium roseum. Journal of Agricultural Food Chemistry, v. 30, p. 106-109, 1982. https://doi.org/10.1021/ jf00109a024

Gilman, J. C. A manual of soil fungi. Ames: Iowa State University Press, 2008.

Gautam, K.; Rao, P. B.; Chauhan, S. V. Efficacy of some botanicals of the Family Compositae against Rhizoctonia solani Kuhn. Journal of Mycology and Plant Pathology, v. 33, p. 230-235, 2003.

Gupta, U. P.; Govindaiah, P.; Dutta, R. K. Plant extracts on non-chemical approach to control 
Fusarium disease of mulberry. Current Science, v. 77, p. 406-409, 1996.

Jantasorn, A.; Moungsrimuangdee, B.; Dethoup, T. In vitro antifungal activity evaluation of five plant extracts against five plant pathogenic fungi causing rice and economic crop diseases. Journal of Biopesticides, v. 9, no. 1, p. 1-7, 2016.

Jobling, J. Essential oils: A new idea for postharvest disease control. Sydney: Sydney Postharvest Laboratory Information Sheet, 2000. Available from: <http://www. postharvest.com.au/gfv_oils.pdf $>$. Accessed on Jul. 10, 2008.

Kaul, M. K. Medicinal plants of Kashmir and Ladakh, temperate and cold arid Himalaya. New Delhi, India: Indus Publishing Co., 1997.

Khandare, K. R.; Vasait, R. D. Use of biopotentials of plant extracts of medicinal importance against pathogenic fungi Fusarium oxysporum. Bioscience Discovery, v. 8, no. 1, p. 87-92, 2017.

Kiraly, Z.; Klement, Z.; Solymosy, F.; Voros, J. Methods in plant pathology with special reference to breeding for resistance to breeding for resistance. New York: Elsevier Publishing Co., 1974.

Koka, J. A.; Wani, A. H.; Bhat, M. Y.; Parveen, S. Antagonistic activity of Trichoderma spp. against some fungi causing fungal rot disease of brinjal. Trends in Biosciences, v. 10, no. 16, p. 2844-2846, 2017.

Korsten, L. Advances in control of postharvest diseases in tropical fresh produce. International Journal of Postharvest Technology and Innovation, v. 1 p. $48-61,2006$. https://doi.org/ 10.1504/IJPTI.2006.009181

Mitcham, E. J.; Mitchell, F. G. Post-harvest handling systems: pome fruits. In Kader, A. A. (Ed). Post-harvest technology of horticultural crops. 3. ed. Oakland, CA: University of California, Agriculture and Natural Resources, 2002. p. 334-344.

Oyelana, O. A.; Durugbo, E. U.; Olukani, O. D.; Ayodele, E. A.; Aikulola, Z. O.; Adewole, A. I. Antimicrobial activity of Ficus leaf extracts on some fungal and bacterial pathogens of Dioscorea rotundata from Southwest Nigeria. Journal of Biological Sciences, v. 11, no. 5, p. 359-366, 2011. https://doi.org/10.3923/ jbs.2011.359.366

Pandey A. In vitro study of efficacy of Mancozeb against Trichothecium roseum on eggplant (Solanum melongena L.). International Journal of Medicinal Research, v. 1, p. 1-5, 2010.

Pawar, B. T. Antifungal activity of some fruit extracts against seed-borne pathogenic fungi. Advanced Bioresearch, v. 4, no. 3, p. 95-97, 2013.

Parveen, S.; Ganie, A. A.; Wani, A. H. In vitro efficacy of some fungicides on mycelial growth of Alternaria alternata and Mucor piriformis. Archives of Phytopathology and Plant Protection, v. 46, no. 10, p. 1230-1235, 2013. https://doi.org/10.1080/03235408. 2013.763617

Parveen, S.; Wani, A. H.; Bhat, M. Y.; Koka, J. A. Biological control of postharvest fungal rots of rosaceous fruits using microbial antagonists and plant extracts: A review. Czech Mycology, v. 68, no. 1, p. 41-66, 2016. https://doi.org/10.33585/cmy.68102

Raji, R.; Raveedran, K. Antifungal activity of selected plant extracts against phytopathogenic fungi Aspergillus niger. Asian Journal of Plant Science and Research, v. 3, no. 1, p. 13-15, 2013.

Sengul, M.; Yildiz, H.; Gungor, N.; Cetin, B.; Eser, Z.; Ercisli, S. Total phenolic content, antioxidant and antimicrobial activities of some medicinal plants. Pakistan Journal of Pharmacy Science, v. 22, no. 1, p. 102-106, 2009.

Shukla, V.; Naik L. B. Agro-techniques of solanaceous vegetables. In: Chadha, K. L.; Kalloo, G. (Eds.). Advances in horticulture: Vegetable crops. Part 1. New Delhi: Malhotra Pub. House, 1993. v. 5.

Singh, D.; Sharma, R. R. Postharvest diseases of fruit and vegetables and their management. In: Prasad, P. (Ed.). Sustainable pest management. New Delhi, India: Daya Publishing House, 2007.

Snowdon, A. L. A colour atlas of postharvest diseases and disorders of fruits and vegetables: General introduction and fruits. Cornell: Wolfe Scientific, 1990.

Thakur, K. D.; Khune, N. N.; Sabley, J. E. Inhibition of some cotton pathogens by plant 
extracts. PKV Research Journal, v. 19, p. 39-41, 1995.

Tomkin and Trout. Pricking by entomological pins. (C-Dass Gupta and Mandal: 1989). 1931.

Tripathi, P.; Dubey, N. Exploitation of natural products as an alternative strategy to control postharvest fungal rotting of fruit and vegetables. Postharvest Biology and Technology, v. 32, no. 3, p. 235-245, 2004. https://doi.org/10.1016/j.postharvbio.2003. 11.005

Wani, A. H. An overview of the fungal rot of tomato. Mycopathology, v. 9, no. 1, p. 33-38, 2011.
Watanabe, T. Pictorial atlas of soil and seed fungi: Morphologies of cultured fungi and key to species. 2. ed. Boca Raton, Florida: CRC Press, 2002.

Welch, A. W.; Jenkins, S. F.; Averre, C. W. Trichothecium fruit rot on greenhouse tomatoes in North Carolina. Plant Disease Reporter, v. 59, p. 255-257, 1975.

Zabka, M. K.; Drastichova, A.; Jegorov, J. S.; Nedbal, L. Direct evidence of plantpathogenic activity of fungal metabolites of Trichothecium roseum on apple. Mycopathologia, v. 162, p. 65-68, 2006. 